\title{
Caught in a sandstorm: an assessment of pressures on communal pastoral livelihoods in the Kalahari Desert of Botswana
}

\author{
Diphetogo Mosalagae ${ }^{1}$ and Kabo Mogotsi ${ }^{*}$
}

\author{
* Correspondence: \\ kbmogotsi@yahoo.com \\ ${ }^{2}$ Animal Production and Range \\ Research Division, Department of \\ Agricultural Research, Ministry of \\ Agriculture, P. O. Box 10275 \\ Francistown, Botswana \\ Full list of author information is \\ available at the end of the article
}

\begin{abstract}
Despite their importance to rural livelihoods, the economic and environmental sustainability of contemporary communal pastoral systems of the Kalahari is increasingly being put under scrutiny. Using data collected from a survey of randomly selected pastoral households from two districts of Ghanzi and Kgalagadi South, Botswana, this paper outlines the major constraints affecting contemporary extensive pastoral systems. Because of the prevailing semi-arid climate, recurrent drought outbreaks were cited as a common challenge in both study areas together with lack of fenced grazing areas. Stock theft was also highlighted as a challenge, even though it was more pronounced in Kgalagadi South. In Ghanzi area, the other important challenges included loss of livestock due to predation, while stray animals, stock theft and loss of livestock due to road accidents were equally important. Kgalagadi South pastoral households experienced serious shortage of drinking water for their livestock, followed by inadequate grazing land and limited access to distant markets. The preceding, together with several other less prominent challenges revealed in this study, exert pressure on pastoral livelihoods. There is need, therefore, to address these perceived challenges and strengthen resilience through effective policy reviews to secure rural livelihoods.
\end{abstract}

Keywords: Borehole, Drought, Indigenous knowledge, Land tenure, Livestock, Markets, Predation, Stock theft

\section{Background}

The Kalahari desert ecosystem of Botswana is characterized by inherent climatic uncertainty, particularly rainfall variability, and consequently exhibits low and highly variable biomass productivity. As a result, wildlife and extensive pastoral-based livelihoods have evolved over time as an adaptation to this 'marginal' environment, and fewer alternative land use systems, if any, can claim to be more economically efficient and environmentally sustainable. Livestock production is central to the livelihood of the majority of rural communities in semi-arid Botswana, and it is characterized by two distinct land tenure systems, communal and commercial. Apart from providing subsistence needs such as meat, milk and hides, livestock - particularly cattle - are also socioeconomically important (Keijsper 1993; Mrema and Rannobe 1996). The latter use of livestock, however, has often been undervalued (Abel 1997; Behnke 2008) or simplified due to the growing commercialization of beef (Darkoh and Mbaiwa 2003). Despite the

(c) 2013 Mosalagae and Mogotsi; licensee Springer. This is an Open Access article distributed under the terms of the Creative Commons Attribution License (http://creativecommons.org/licenses/by/2.0), which permits unrestricted use, distribution, and reproduction in any medium, provided the original work is properly cited. 
apparent value of livestock to the rural economy, the agricultural sector has experienced unprecedented decline in overall performance over the years. The sector's contribution to the national economy Gross Domestic Product (GDP) has declined from 40\% since 1966 to less than $2 \%$ currently (GoB 2009a), mainly attributed to the growing importance of mining and tourism sectors. The beef sub-sector still contributes significantly to the total agricultural GDP.

To better understand the context of pastoral changes in Botswana, it is necessary to highlight past major policy shifts. Under the traditional system of land tenure, land was always regarded as communal and tribal chiefs allocated land for arable and/or grazing use. The traditional system was replaced in 1968 by the Tribal Land Act which introduced decentralized Land Boards to administer land, instead of chiefs. The passing of the Tribal Land Act and the establishment of Land Boards did not fundamentally change the concepts of land tenure (Greenhow 1978). However with time, the traditional communally-owned rangelands in the eastern Kalahari were perceived by the government to be overstocked and overgrazed by livestock and thus degraded. Buying into the 'tragedy of the commons' narrative popularized by Hardin (1968), the Tribal Grazing Land Policy (TGLP) advocated for structural reforms to the country's livestock industry, to ultimately enhance national economic and social development (GoB 1975). Subsequently, part of the tribal grazing land was demarcated into ranches. The specific objectives of TGLP were to:

1. Improve range management by preventing overgrazing and further degradation through paddocking and rotational grazing. Individual owners or syndicates of large herds ( $>400$ animals) were to be moved off communal lands into fenced, boreholefocused ranches of uniform size.

2. Increase livestock productivity and farmers' income by promoting better management practices such as daily watering, selective breeding and early weaning.

3. Promote social equity by retaining only small-scale farmers on communal lands and thus allowing some room to improve their livelihoods.

4. Secure the interest of future generations and/or those who were not livestock farmers by reserving some land.

To ease the environmental and social conundrum in the wetter eastern Botswana, which held 70\% of the national herd (Thomas and Sporton 1997), the TGLP encouraged development further west into the more arid Kalahari desert, aided by borehole installations. But with time, it became apparent that the TGLP was based on false assumptions. Firstly, there was not enough land to demarcate into viable livestock ranches as previously assumed. Secondly, overriding abiotic factors like rainfall, fire and drought characteristic of the non-equilibrium nature of semi-arid and arid environments called into question the coupling of plant-livestock relations emphasized by the equilibrium theory in grazing systems (Behnke et al. 1993; Scoones 1995). Since density of herbivores is not the only driver of vegetation dynamics, it followed that destocking per se as a management tool would not be effective. The final assumption of TGLP was that those allocated ranches will stay as ranches. To the contrary, ranch owners employed dual grazing rights, where they let their herds onto the commons during wet grazing periods and retreated to their exclusive ranches during dry seasons. Overall, 
extensive reviews of the TGLP have concluded that it failed to address its objectives (Tsimako 1991; White 1993; Frimpong 1995).

Upon realizing the shortcomings of TGLP, the government introduced the National Policy on Agricultural Development (NPAD) in 1991. The aim of NPAD was to provide subsidies to improve productivity in the livestock sub-sector by promoting the sustainable use of rangeland resources through fencing of communal grazing areas (GoB 1991). So in essence, the fencing component of NPAD simply accelerated the implementation of TGLP and failed to tackle some of the earlier concerns like dual grazing rights. But not everyone was practicing pastoralism. Some ranches had displaced nonpastoral populations and denied them access to natural resources of land, water, veld products and animals (Hitchcock 1978). So for other traditional rural livelihoods such as hunting and gathering, part of the reserve land was later demarcated into Wildlife Management Areas (WMAs) in an attempt to balance the scales. WMAs are multipleuse areas combining wildlife conservation with the creation of economic opportunities for the rural population (GoB 1999). Intense developments within WMAs such as borehole drilling are prohibited, while hunting is controlled through permits or total bans. There are complementary polices and pieces of legislation predicated on sustainable utilization of natural resources also governing these areas, such as the Wildlife Conservation Policy (1986), Tourism Policy (1990), National Conservation Strategy (1990), Wildlife Conservation and National Parks Act (1992), Tourism Act (1992) and Community Based Natural Resource Management (CBNRM) concept.

Given the historical context above, the current paper focuses on contemporary pastoral livelihoods under communal land tenure. While once viewed as destructive, economically irrational and archaic (GoB 1975; FAO 2001), the extensive livestock production system continues to directly and/or indirectly support a large rural population and the importance of livestock still transcends many sectors. Approximately 39\% - 791,700 people - of Botswana's human population resides in rural areas, out of a total of 2.03 million. Botswana's cattle population stood at 2.55 million in 2011 (GoB 2013), where grazing in communal rangelands accounted for $86 \%$ of the cattle and $71 \%$ of farmers in Botswana, while private grazing in ranches accounted for $14 \%$ of the national cattle herd and $5 \%$ of the land area. Though the traditional communal, open access grazing lands are often dismissed as unproductive relative to modern ranches (APRU 1980), empirical evidence does not always reflect this (Behnke 1985; deRidder and Wagenaar 1986). For example, looking at previous work in Botswana, Davies and Hatfield (2007) noted that production in cash, energy and protein terms per hectare under communal areas exceeds by at least three times per hectare returns from ranches, even though technical production parameters are lower. The latest statistics show that the traditional sector has consistently had higher cattle birth rates than the commercial sector (54.4\% and 38.9\%, respectively), but this achievement is compromised by the high mortality rates observed in communal lands relative to commercial ranches (GoB 2013). The rate of mortality in communal grazing lands was $6.6 \%$, while commercial ranches experienced $1.6 \%$ mortality rate. Off-take rates in the commercial sector increased from $12.5 \%$ in 2010 to $13.5 \%$ in 2011 while the national rate dropped from $8.0 \%$ to $6.9 \%$ during the same period (GoB 2013).

If the livestock sector is to continue being the mainstay of rural livelihoods in future, then there should be deliberate efforts to maintain and/or improve its productivity. But first, the factors linked to the observed decline in livestock productivity need to be 
identified, understood and appreciated. While some factors have been perceived as affecting livestock production in Botswana (GoB 1991; Mrema and Rannobe 1996; Burgess 2002; CAR 2005; BIDPA 2006), these are more often than not at national level and thus grossly aggregated, with a few exceptions (e.g. Kgosikoma 2006). Furthermore, the process of identifying problems at the local level is influenced by 'outsiders' in the form of environmental managers/experts and policy-makers and may end up not receiving support from the community (Fraser et al. 2006). A more comprehensive approach must consider the interests, positions and needs of pastoralists so as to guide decision-makers and develop a suitable and legitimate process of communal land and resource tenure that fits with both the priorities of pastoralists as well as the government (Flintan and Cullis 2010).

This study therefore set out to identify and characterize the major constraints faced by contemporary extensive livestock production systems in the west and south-western semi-arid Kalahari of Botswana, as perceived by the pastoral communities. Knowledge about challenges hampering the livestock sector will guide the timing and form of intervention measures, as well as better inform policy designed to halt and reverse the decline in livestock production and hence ensure continued sustainability of rural livelihoods.

\section{Study area}

The study was conducted in the western Kalahari region of Botswana, in Ghanzi and Kgalagadi Districts. The Ghanzi study area covered Ghanzi village $\left(21^{\circ} 42^{\prime} \mathrm{S}, 21^{\circ} 49^{\prime} \mathrm{E}\right)$ and the surrounding communal grazing lands. The area is characterized by deep, infertile Kalahari sands. Rainfall is unimodal and averages $375 \mathrm{~mm}$ per annum. Maximum mean daily temperatures reach $33^{\circ} \mathrm{C}$ to $45^{\circ} \mathrm{C}$ and $22^{\circ} \mathrm{C}$ in summer and winter months, respectively, with a minimum of $4^{\circ} \mathrm{C}$ to $-5^{\circ} \mathrm{C}$ in winter months. The vegetation is classified as tree and bush savanna, dominated by woody species such as Terminalia sericea and Boscia albitrunca, while the herbaceous layer includes grasses like Eragrostis lehmanniana, Pogonarthria squarrosa and Digitaria eriantha.

The second study area was Kgalagadi South sub-district within the Kgalagadi District and covered Tsabong village $\left(26^{\circ} 112^{\prime \prime} \mathrm{S}, 22^{\circ} 24^{\prime} 20^{\prime \prime} \mathrm{E}\right)$ and the surrounding communal grazing areas. Rainfall also follows a unimodal pattern, falling mainly between the months of November and March with a long-term annual average of less than $250 \mathrm{~mm}$ and high variability. Maximum temperatures reach $45^{\circ} \mathrm{C}$ in summer, and minimum winter temperatures can be as low as $-4^{\circ} \mathrm{C}$. The vegetation is classified as shrub/bush savanna, dominated by woody species such as Acacia erioloba, Acacia mellifera and Acacia luederitzii, while grasses include E.lehmanniana, Stipagrostis uniplumis and Schmidtia kalahariensis.

The introduced exotic Prosopis tree species has increasingly become an important invader, especially in proximity to human settlements. Towards the extreme south-west , bare rolling sand dunes are visible and in some areas are covered by layers of grass.

In both study areas, small-scale agriculture is practiced, mainly dominated by livestock rearing in communal, open access grazing lands referred to as cattle posts or locally known as meraka. Beef and game ranching is also notably present in this part of the country. Limited small-scale rain-fed crop cultivation is spread over both the districts, mainly including maize, sorghum, beans and melons. Though both study areas lie within the Kgalagadi (Kalahari) desert ecosystem, the second study site of Kgalagadi South is in the driest and least inhabited region of Botswana, and thus, in some areas 
crop cultivation is not practiced at all. This widened geographical scope enabled the study to capture differences that may be due to climatic and related ecological differences.

\section{Methods}

Data collection

In each purposively selected study area, pastoral households ${ }^{\mathrm{a}}$ were randomly selected with the aid of extension agents from the Ministry of Agriculture and the local authorities. Because absentee ownership is common, appointments were made in advance with heads of each household, who were then interviewed at their preferred time. In Ghanzi area, 24 pastoral households were surveyed,while 16 were chosen for the Kgalagadi South study area. The Kgalagadi South area, as earlier noted, is the driest and least inhabited in Botswana. Subsequently, pastoral households are relatively fewer and sparsely distributed, thus resulting in a serious challenge in terms of accessibility through the sandy terrain. The size of the area to be covered as well as the very nature of pastoral systems located in remote areas meant that only four-wheel-drive vehicles could be used.

A structured questionnaire with open-ended, multiple-response and dichotomous questions was used to collect data. A pilot test run was conducted prior to the main survey, and the final questions were amended accordingly. The survey questionnaire collected data on socio-economic variables of households and their livestock management practices including feed and water resources, markets, labour usage as well as their perceived constraints hampering the sustainability of the extensive livestock production system under investigation. To avoid misinterpretation, the interviews were conducted in Setswana, the national language generally understood by the respondents. In addition to direct observations in the field (including participant observation), conversational exchanges with key informants such as extension agents, representatives of farmer groups/committees and local headmen/chiefs complemented the survey.

\section{Data analysis}

Data were coded and thereafter analyzed using the frequency procedure of SAS (SAS 2005) for socio-economic characteristics of respondents and related variables. The chi-square $\left(\chi^{2}\right)$ test was used to confirm whether respondents were uniformly distributed or not among the groups for each variable or, for the two-way tables, to measure the interaction or strength of association between any two variables. The inferential tests were declared significant or not using the calculated $\chi^{2}$ test $p$ value against the $5 \%$ level of significance.

\section{Results}

\section{Socio-economic characteristics}

The socio-economic characteristics of the respondents are shown in Table 1.

The pastoral households surveyed were mostly headed by older males ( $\geq 40$ years) in both study areas, and the majority (70\%) had some formal education. In Ghanzi, the main sources of income in decreasing order of importance were as follows: sales from agricultural activities, formal employment and monthly pension. Kgalagadi South households earned their income mainly from animal and crop agriculture, and only $2 \%$ had some form of formal employment. The most reared and highly valued livestock were cattle and small stock (goats and sheep), though cattle dominated in Ghanzi while 
Table 1 The socio-economic characteristics of pastoral households in the study areas

\begin{tabular}{|c|c|c|c|}
\hline \multirow[t]{2}{*}{ Variables } & \multicolumn{3}{|c|}{ Study area } \\
\hline & Ghanzi (\%) & Kgalagadi South (\%) & Total (\%) \\
\hline \multicolumn{4}{|l|}{ Gender $^{a}$} \\
\hline (i) Male & $19(48)$ & $15(38)$ & $34(85)$ \\
\hline (ii) Female & $5(13)$ & $1(3)$ & $6(15)$ \\
\hline \multicolumn{4}{|l|}{ Age group $^{a}$} \\
\hline (i) 21 to 39 years & $4(10)$ & $2(5)$ & $6(15)$ \\
\hline (ii) 40 to 65 years & $19(48)$ & $8(20)$ & $27(63)$ \\
\hline (iii) $>65$ years & $1(3)$ & $6(15)$ & $7(18)$ \\
\hline \multicolumn{4}{|l|}{ Educationlevel $^{a}$} \\
\hline (i) Illiterate & $7(18)$ & $5(13)$ & $12(30)$ \\
\hline (ii) Formal education & $17(43)$ & $11(28)$ & $28(70)$ \\
\hline \multicolumn{4}{|l|}{ Main source of income } \\
\hline (i) Employed in agriculture & $13(33)$ & $14(35)$ & $27(68)$ \\
\hline (ii) Formal employment & $7(18)$ & $2(2)$ & $9(23)$ \\
\hline (iii) Pension & $4(10)$ & $0(0)$ & $4(10)$ \\
\hline \multicolumn{4}{|l|}{ Livestock ownership } \\
\hline (i) Cattle & $24(65)$ & $13(35)$ & $37(100)$ \\
\hline (ii) Goats & $16(52)$ & $15(48)$ & $31(100)$ \\
\hline (iii) Sheep & $5(31)$ & $11(69)$ & $16(100)$ \\
\hline (iv) Equine & $19(54)$ & $16(46)$ & $35(100)$ \\
\hline (v) Chickens & $19(95)$ & $1(5)$ & $20(100)$ \\
\hline
\end{tabular}

${ }^{\mathrm{a}}$ Head of household.

more households kept small stock in Kgalagadi South area. Equines, mostly horses and donkeys, were also reared in relatively high numbers, commonly used as transport when traversing the extensive deep sand and predator-filled Kalahari terrain.

\section{Livestock management practices}

The main livestock management practices undertaken by pastoral households in the study areas are shown in Table 2.

The Kalahari desert is characterized by the absence of surface water for most periods of the year. Thus, in this study, most pastoral households relied on underground water through sinking of boreholes. Syndicate boreholes were used more (68\%) in both study areas, where a group of pastoral households shared the same water point. Syndicates are organizations in which a group of people come together for the common purpose of owning and operating a borehole (Hitchcock 1978), and members contribute equally towards the cost of drilling, daily running and maintenance of the borehole. The distances from the homesteads to livestock watering points varied among households. In Ghanzi, $71 \%$ of households indicated that their main source of drinking water for livestock was within a distance of $1 \mathrm{~km}$, while $29 \%$ had to travel for more than $1 \mathrm{~km}$ to livestock water points. A similar trend was observed in Kgalagadi South, where 75\% and $25 \%$ of households had to cover distances of less than $1 \mathrm{~km}$ and greater than $1 \mathrm{~km}$, respectively, to reach livestock water points.

The livestock were housed under improved structures (93\%), which were mostly built using treated poles and fence, while some even had feed and water troughs as well as 
Table 2 Some livestock management practices undertaken in the study areas

\begin{tabular}{|c|c|c|c|}
\hline \multirow[t]{2}{*}{ Variables } & \multicolumn{3}{|c|}{ Study area } \\
\hline & Ghanzi (\%) & Kgalagadi South (\%) & Total (\%) \\
\hline \multicolumn{4}{|c|}{ Source of livestock drinking water } \\
\hline (i) Own borehole & $6(15)$ & $7(18)$ & $13(33)$ \\
\hline (ii) Syndicate borehole & $18(45)$ & $9(23)$ & $27(68)$ \\
\hline \multicolumn{4}{|l|}{ Gender of labour } \\
\hline (i) Males & $11(28)$ & $15(38)$ & $26(65)$ \\
\hline (ii) Females & $2(5)$ & $0(0)$ & $2(5)$ \\
\hline (iii) Males and females & $11(28)$ & $1(3)$ & $12(30)$ \\
\hline \multicolumn{4}{|l|}{ Reliability of labour } \\
\hline (i) Very reliable & $16(40)$ & $3(8)$ & $19(48)$ \\
\hline (ii) Reliable & $5(13)$ & $7(18)$ & $12(30)$ \\
\hline (iii) Not reliable & $3(8)$ & $5(13)$ & $8(20)$ \\
\hline (iv) Do not know & $0(0)$ & $1(3)$ & $1(3)$ \\
\hline \multicolumn{4}{|l|}{ Type of livestock housing } \\
\hline (i) Bush enclosures (kraals) & $1(3)$ & $2(5)$ & $3(8)$ \\
\hline (ii) Improved shelter & $23(55)$ & $14(35)$ & $37(93)$ \\
\hline \multicolumn{4}{|c|}{ Mineral supplementation of livestock? } \\
\hline (i) Yes & $22(55)$ & $15(38)$ & $37(93)$ \\
\hline (ii) No & $2(5)$ & $1(3)$ & $3(8)$ \\
\hline
\end{tabular}

shaded areas from corrugated iron sheets. The remainder of the households built simple bush enclosures using branches of the thorny Acacia tree species. The animals were housed in one group, except where young calves were separated from the rest of the herd overnight to allow hand milking of lactating cows in the morning for household consumption. Pregnant cows, lactating cows and calves grazed closer to the homesteads as they require water more often than other types of livestock and also for safety from marauding predators.

In contrast to most traditional extensive pastoral systems (Coppock and Sovani 1999; FAO 2001; ESAP 2003), there was notable mineral supplementation of livestock undertaken in both study areas even though the natural rangeland still provided the bulk of the livestock feed. Apart from the popularly used coarse salt (88\%) and dicalcium phosphate (63\%), other supplements included beef finisher meal (30\%), bull ration (15\%), drought pellets (13\%) and assorted minor supplements of sorghum bran/molasses/mineral blocks (40\%). The use of these supplements, however, was mostly done on an ad hoc basis, and it was more pronounced during the dry season.

The gender of workers in surveyed pastoral systems was highly skewed towards males (65\%). Labour is particularly essential for herding and in filling troughs with drinking water for cattle. Herding varies with seasons and may cover distances of up to $20 \mathrm{~km}$ daily. In addition, other duties include everyday livestock handling activities such as milking, branding, dehorning, castration, hoof trimming and occasional maintenance of borehole and livestock housing structures. In essence, labourers are expected to multitask and be flexible. Only a relatively small proportion (20\%) of labourers was deemed as unreliable. While labourers can plan and execute daily chores on their own, the 'serious' decision-making powers are still exclusively retained by the livestock owner. These decisions include, among others, selling or killing of any livestock, granting approval for new 
incoming herds on the same grazing area, as well as when and where to move animals in times of extended drought periods.

\section{Production constraints}

The challenges faced by pastoral communities in Ghanzi and Kgalagadi South are reflected in Figure 1.

In Ghanzi area, the most important challenges included loss of livestock due to predation (44\%), drought (36\%) and lack of fenced grazing areas (12\%), while stray animals, stock theft and loss of livestock due to road accidents were all equally important (8\% each). Kgalagadi South pastoral households experienced problems of drought and shortage of drinking water for livestock ( $38 \%$ each), followed by stock theft, limited grazing land, limited access to distant markets (19\% each) and lack of fenced grazing areas (13\%). As many as 23 constraints were encountered by pastoralists overall, but only 6 were common to both study areas. Though numerous, some of the mentioned challenges were complex and intricately linked. For example, lack of fenced grazing areas, uncontrolled breeding, stray animals and predation by carnivores are all functionally linked. Another example of associated challenges is overgrazing, poor range conditions, diseases and poisonous or injurious plants killing livestock. Only $8 \%$ and 13\% of households did not mention any challenges in Ghanzi and Kgalagadi South, respectively.

\section{Discussion}

\section{Production constraints}

Only the five most important constraints, as perceived by pastoral households, are further discussed next. Both areas experienced drought. In Ghanzi, other constraints included predation, drought, unfenced grazing areas, stray animals and loss of livestock to road accidents. Kgalagadi South pastoral households cited shortage of drinking water for livestock in addition to stock theft, limited grazing areas and limited access to distant markets.

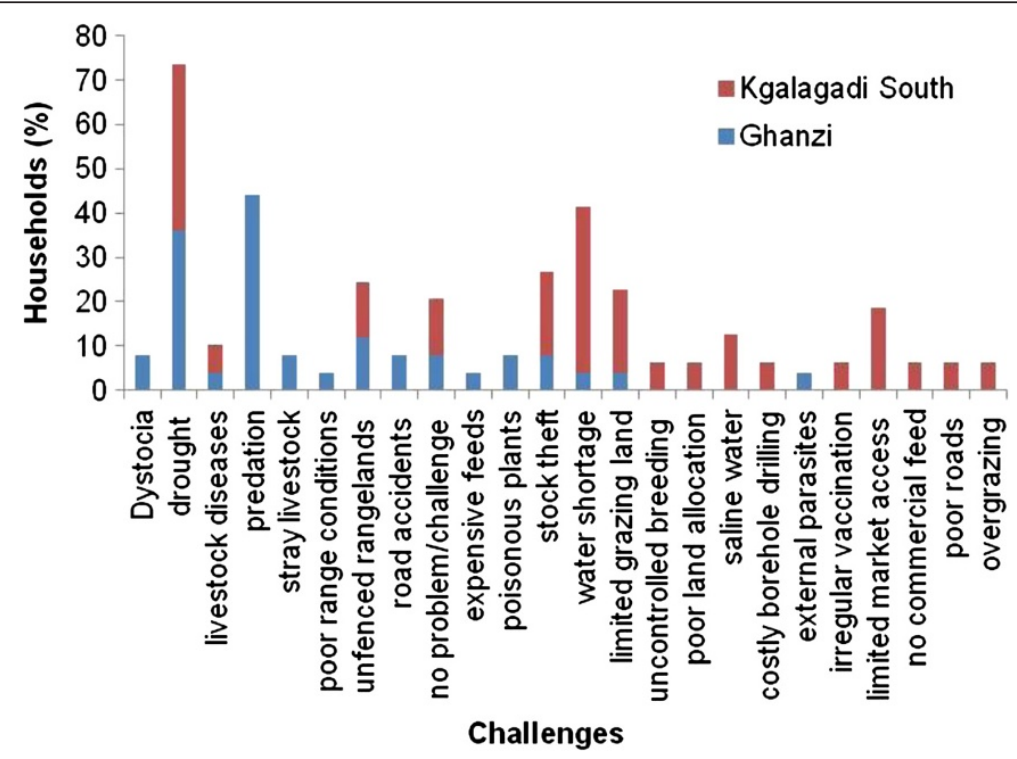

Figure 1 Challenges faced by pastoral households in Kgalagadi South and Ghanzi study areas. 


\section{Drought}

Droughts are common phenomena in semi-arid environments such as the Kalahari desert ecosystem of Botswana (Sandford 1979; Holm and Morgan 1985; Fako and Molamu 1995; Mogotsi et al. 2011a). Four broad categories of drought are recognized. Meteorological drought is usually measured by significant departures from normal precipitation observed over some period of time. Agricultural drought occurs when there is limited soil moisture to support crops and natural vegetation and results in less forage production than expected. Hydrological drought refers to deficiencies in surface and sub-surface water supplies to support established uses. Socio-economic drought is recognized when physical water shortage tangibly affects people in terms of their behaviour and options (Wilhite and Glantz 1985; IFAS 1998; Thurow and Taylor 1999). Whichever perspective one chooses to look at drought, the underlying cause is inadequate amount of moisture around which systems have stabilized.

Pastoral communities in rural Botswana have historically been and continue to be exposed to drought hazards (Holm and Morgan 1985; Mogotsi et al. 2011a). Expectedly, the two study areas of Ghanzi and Kgalagadi South both cited drought occurrence, irrespective of frequency and intensity, as a challenge. While other livelihood strategies like crop farming in higher rainfall areas view drought as a once-off temporary disruption, extensive pastoral systems are themselves inherently adapted to inevitable drought risks. This is achieved, in part, through risk-spreading and flexibility (Omosa 2005) such as livestock herd diversity and accumulation of large stock numbers so as to ensure long-term survival following drought losses (Barrow et al. 2007). In Botswana, past studies have estimated the minimum threshold number of animals in a herd to be no less than 40 (Carl Bro International 1982; CAR 2006) to start a self-sustaining subsistence cattle post. The complex role drought plays in such subsistence-based livelihoods in Botswana has been comprehensively elaborated (Mogotsi et al. 2013). A typical pattern usually emerges - inadequate rainfall amounts result in low natural pasture production on which livestock depend. Thus, areas in the proximity of livestock water points are overutilized and rapidly deteriorate, forcing animals to move further and further away in search of better grazing areas. The increased distance between better grazing areas and drinking water points ultimately takes its toll on livestock through loss of weight, decreased calving rates and, in extended drought periods, death of animals. The increased exposure to frequent drought episodes has the potential to erode resilience of pastoral systems and render them vulnerable (FAO 2009; Mogotsi et al. 2012).

\section{Livestock predation}

The communal grazing area around Ghanzi borders other contrasting land use systems, mainly private freehold and leased ranches, WMAs and the Central Kalahari Game Reserve. With such close proximity to each other, the area experiences human-wildlife conflict. There is inevitable loss of livestock to predation by carnivores such as lions (Panthera leo), wild dogs (Lycaon pictus), brown hyenas (Parahyaena brunnea), spotted hyenas (Crocuta crocuta) and cheetahs (Acinonyx jubatus). The livestock-carnivore conflict is undoubtedly an emotive issue. Tourism generates significant revenue for Botswana's economy and is second only to the mining sector. Furthermore, wildlife tourism is seen as a viable diversification option away from the predominantly diamond mining-dependent economy. On the other hand, livestock are the backbone of subsistence 
pastoral livelihoods, and thus, losses, particularly from carnivore predation, are rarely tolerated or accepted (GoB 2005). To a small-scale farmer, loss of even one animal can translate into significant economic and social costs, while outsiders may view this simply on numerical terms and classify it as insignificant. All livestock are affected by predation, though calves, goats and sheep are particularly vulnerable and thus targeted. Also, it emerged that pastoral households whose animals are not protected at night by enclosures/kraals or those with kraals that are not predator-proof suffer the most losses. If kraals are not properly constructed or maintained, predators can find an opening in the perimeter lining, or dig under the kraal and gain access, or simply climb/leap over. Hyenas were the predators singled out for causing the most livestock losses, and households showed greater animosity towards them. On some occasions, animals are targeted during daylight if no herding is done due to lack of reliable labour or if no guard dogs are used.

As part of a strategy to reduce and manage the conflict between humans and predators, the government through the Department of Wildlife and National Parks provides financial compensation to farmers who lose livestock to specified predators (GoB 2009b), even though amounts paid are generally deemed unsatisfactory (Kgathi et al. 2012). This discontent should be rectified accordingly since it is the individual pastoralists who are asked to sacrifice and compromise their livelihoods for the greater good of the nation and those who benefit directly from tourism. The adoption of such concepts as CBNRM acknowledges this point and strives to meet the needs of rural communities through sustainable economic exploitation of wildlife while achieving the country's resource conservation objectives. Niamir-Fuller et al. (2012) further assert that integration of wildlife management and livestock can offer multiple and complementary income sources, provided that stronger governance and regulatory co-management are in place.

\section{Inadequate drinking water for livestock}

Pastoral livelihoods are climate dependent, driven particularly by rainfall in the semiarid regions of Africa, the Near East, the New World and Australia (FAO 2001). In Botswana, the mean annual rainfall total ranges from less than $250 \mathrm{~mm}$ with a coefficient of variability of $45 \%$ in the extreme south-west part of the country to over 600 $\mathrm{mm}$ with a coefficient of variability of $25 \%$ in the extreme northeast (Bhalotra 1987). The low, erratic rainfall and associated excessive evaporation rates make water a limiting factor for pastoral communities of Ghanzi and Kgalagadi South. The area is subsequently devoid of large surface water bodies, save for the temporary water following summer rains in numerous pans dotted across the landscape. It is this patchiness of resources that has necessitated the opportunistic management that has kept the fragile and dynamic Kalahari ecosystem delicately balanced. Though underground water is accessible since the advent of borehole technology, there is still the added challenge of poor-quality water (high salinity) in some places (Hitchcock 1978; Mogotsi et al. 2011a). There is also the associated risk of hitting blanks, as well as debates on whether there is enough recharge to compensate for increased extraction of water in the Kalahari (Kgathi 1999; deVries et al. 2000; duPlessis and Rowntree 2003). The often prohibitive costs of drilling are beyond most individual pastoral households (CAR 2005), unless subsidized by the government (GoB 2002). Thus, as also revealed in this study, syndicates or farmer groups jointly own and manage boreholes or an individual borehole owner (with exclusive water rights) permits other users access to water. 
According to Nori et al. (2005), accessing resources and services of neighbours is a vital element for pastoralists, and therefore, the resource tenure system needs to be flexible enough to accommodate negotiations and arrangements among different groups and levels, depending on needs and on resources availability. Reciprocity is a valuable principle in such circumstances and represents some form of social capital.

\section{Limited grazing land}

Some Kgalagadi South pastoralists decried the inadequate grazing land for their livestock. Arid and semi-arid environments are climatically unpredictable, characterized by low net primary productivity and high resource variability. To counter this uncertainty, some form of pastoral mobility is essential to ensure that livestock have continuous access to adequate quality feed supplies and thus sustain the production system (Thomas et al. 2000). However, based on earlier assumptions that extensive communal pastoral systems were inefficient and irrational (Hardin 1968), vast tracts of supposedly unused/ empty land were expropriated and sedentarization was encouraged through modern fenced ranching systems. On the contrary, the unused/empty spaces were already inhabited by transhumant rural communities (Hitchcock 1978). As earlier noted, under the Tribal Grazing Land Policy of 1975, part of the communal land was demarcated into privately-owned ranches under 50-year leases, in a bid to combat perceived range degradation. The failures of TGLP are well documented (White 1993; Frimpong 1995) as sedentarization conflicts with migration as a strategy for coping with environmental variability and stress (Twyman 2001), including droughts.

Other competing economic activities like wildlife conservation and increasing number of human settlements in close proximity to communal grazing areas also require land. These activities, together with the weakening of traditional rangeland resource management systems, have stretched pastoral livelihoods in arid regions of Kgalagadi South, as they no longer have control over the shrinking land resource. Omosa (2005) argues that adequate resource access determines the sustainability of pastoralism, and by the same extension, it can be argued that pastoral households would have to somehow adapt or face destitution.

\section{Loss of livestock to road accidents}

Ghanzi pastoral households experienced direct loss of livestock due to animal deaths or serious injuries caused by collisions with automobiles, especially along the recently constructed Trans Kalahari Highway cutting across southern Botswana and linking up the country with neighbouring South Africa to the south and Namibia in the west. While other main tarred roads (for example, the eastern A1 highway connecting the cities of Gaborone and Francistown) across the country are fenced to enhance road safety, the Trans Kalahari Highway is not, for fear of wildlife habitat fragmentation and disruption of migration and movement corridors. This situation in turn has contributed to an increased number of accidents involving vehicle collisions with domestic animals from the nearby cattle posts. According to ADBG (2011), data from the Ministry of Works, Transport and Communication reveal that there has been an increase in road accidents of approximately $64 \%$ along this Highway. The reasons for the increased road accidents are attributed to negligence, animals and mechanical deficiencies (ADBG 2011). During extended dry seasons and droughts, some animals may be drawn to the 
remnants of vegetation along the road reserves or lush green grass at the onset of the rainy season while some, especially donkeys and cattle, may sleep on the tarmac road presumably for warmth during winter nights. Furthermore, because of policy changes (for instance, Motor Vehicle Accident Fund and Road Traffic Act), owners may hesitate to claim livestock involved in road accidents as they are likely to be penalized for letting animals wander about and thus causing human injuries/deaths and/or damage to property. It is ironic that while physical infrastructure, particularly road networks, are meant to support other economic sectors including agriculture and tourism, it is the very same roads that are fragmenting habitats and literally killing domestic and wild animals.

\section{Stray animals}

Stray animals were also a challenge to pastoral households in Ghanzi. This was attributed mainly to negligence on the part of herders, who ignore their responsibilities especially after receiving their monthly wages, then 'disappear' and only return after depleting their cash reserves. Absentee owners, often referred to as 'remote control' farmers, were also blamed for animals going astray as they spend most of their time in villages/towns under formal off-farm employment and rarely check on their livestock or the welfare of the herders. In the past, family labour was utilized in pastoral systems - a scenario which has changed as school-going children are no longer available to help out, as well as competition from other emerging sectors like construction for the limited labour pool. Moreover, the latter is now even more protected by the country's labour laws, something perceived in some quarters as a foreign concept which has prompted reluctant adjustments from some livestock owners.

Labourers were traditionally treated as part of the family; even though not adequately remunerated in cash, they were also paid in kind through free accommodation, food and other basic necessities enjoyed by the rest of the household members. In some cases, in return for their labour, herders could be given a few animals to progressively build their own herds. Already, as observed in the current study areas, there is general apathy towards menial jobs like livestock herding, especially among Batswana (citizenry of Botswana) youth. The continued availability of reliable labour is even more critical as pastoral households consist mostly of elderly people, who, even if willing, do no longer have the energy to personally look after their livestock. The ultimate fate of stray animals is governed by the Matimela Act (1969), which provides for the collection of stray livestock in Botswana's districts and the subsequent disposal of animals if unclaimed by the rightful owners after a stipulated period.

\section{Livestock theft}

A related challenge experienced in both study areas is livestock theft, which was, however, more pronounced in Kgalagadi South rangelands. Livestock theft has been on the increase in Botswana (GoB 2011), mainly involving cattle, goats and donkeys. This crime is more prevalent in areas situated along the borders, like Kgalagadi South in proximity to South Africa and the periphery of cities and towns as in the case of Ghanzi. The latter area provides the market demand for livestock products, as is usual in most settlements with higher human populations. In the case of Kgalagadi South, it is mostly the dilapidated sections of fences along the border with South Africa that 
were pointed out as facilitating cross-border stock theft. In Botswana, theft of livestock can occur in several ways (GoB 2011), which include (1) killing lactating cows and stealing pre-weaned and unbranded calves, which are raised then later unlawfully branded and earmarked with the new owners' particulars, (2) unlawful branding of stray livestock which have joined part of the resident herd, (3) slaughtering for immediate consumption, usually individual offenders and (4) slaughtering stock usually by organized criminal syndicates to sell to unsuspecting or conniving butchery owners and bypassing the legal process of inspection of animals before slaughter at Council abattoirs as envisaged in the Livestock and Meat Industries Act (1962).

Because of the socio-economic importance of livestock in the country, the sector is arguably one of the most protected (Jefferis 2005) as all international trade in beef and cattle is prohibited as outlined in the Control of Livestock Industry Act (1968), except when routed through the Botswana Meat Commission (BMC). Traditionally, Batswana pastoral households used a wealth of knowledge acquired and refined over time to identify their animals by the use of marking techniques such as hot iron branding or ear marks and skin colour. While these are useful in identifying the owner of the animal(s), the system cannot adequately identify individual animals and hence the introduction of other techniques like ear tag numbers and lately the use of digital reticular bolus identification technology implemented under the Livestock Identification and Trace-back System. The latter is mostly compliance to regulatory requirements by Botswana's 'lucrative' European Union (EU) beef export market, which emphasizes stringent international standards for food quality and safety as well as disease control. The use of the bolus for curbing livestock theft was therefore an offshoot or by-product of the EU beef traceability requirement and is restricted only to cattle. The reticular bolus, however, was to be replaced with an electronic ear tag coupled with an analogue ear tag as an identification device effective the year 2013. Some farmers ingeniously use plastic ear tags to write down their contact details, usually mobile phone numbers, so that any of their lost animals which have been rounded up may be traced back to them through a simple phone call. All the preceding measures coupled with enforcement of the Stock Theft Act (1996) and other pertinent legislation have greatly eliminated commercialization of cattle raiding/rustling in Botswana, in contrast to other regions of Africa (Hendrickson et al. 1996; Kaimba et al. 2011), where the practice is widespread, sophisticated, more violent and destructive (Mkutu 2010; Schilling et al. 2012).

\section{Unfenced grazing areas}

Unfenced grazing areas were cited as a challenge. At first, one can erroneously conclude that fencing of the commons is what pastoral communities are pining for, despite advice to the contrary (Behnke et al. 1993; Scoones 1995). But on closer scrutiny, the preceding challenges of livestock predation, stray animals and deaths of animals following collisions on highways and so on have part of their root causes in encroachment of pastoral rangelands by other, often competing, land users. The increased pressure on pastoral resources from other stakeholders can be alleviated, in the pastoralists' view, not only by virtual designation or zoning of land but also by physical barriers (i.e. fences) to secure their grazing areas from other users. This is perhaps a desperate response to the continued increase in external pressures on pastoral communities and thus the associated fear of their livelihoods being compromised. This is in line with 
observations made by Hartter et al. (2011), who opined that the presence or absence of resources influences behaviour and management as land use strategies are altered or maintained based on perceptions of risk and resource availability. The land tenure insecurity thus prevails among some pastoral households. As rightly observed by PicaCiamarra et al. (2010), 'it is not the system of land tenure that matters so much as the adequacy and security of tenure that allow for efficient and sustainable use of resources'. While there is provision for fencing of community grazing areas under the Agricultural Policy of 1991, implementation of the same is painstakingly slow.

\section{Restricted access to markets}

In an increasingly cash-driven global economy, contemporary pastoralists are forced to adapt or risk vulnerability and marginalisation (Nori et al. 2005). The growing demand for livestock products like meat and milk due to population growth, urban migration and urban income growth (Delgado et al. 1999) offers opportunities for pastoral communities in the so-called 'Livestock Revolution'. This is further supported by some governments, who often cite low livestock off-take rates and low average carcass weights in communal rangelands as evidence for room for improvement. And when markets continue to be 'underutilized' by pastoralists, then frustration sets in. The reasons for this 'underutilization' are well articulated by DFID (2011), among which are the poor fit between pastoralists' objectives in selling their livestock and the demands of the market, as well as long and risky marketing chains. Under traditional subsistence pastoral systems, livestock are commonly kept not to make money but rather to save money (Davies and Hatfield 2007). Furthermore, it is difficult to facilitate poverty alleviation and eradication when the pastoral communities themselves are economically isolated from large urban markets due to logistical and transport costs (Chadwick et al. 2008), as experienced by some households in Kgalagadi South. The BMC, which has the monopoly of all beef exports from Botswana, is located in Lobatse some $500 \mathrm{~km}$ from Tsabong in Kalagadi South, and thus, local butcheries are sometimes preferred even though they pay less or have little capacity to absorb high livestock sales. Kgosikoma (2006) found a similar trend in the same study area especially during drought years. In a study in East Africa by McPeak (2001), higher market access by pastoralists was associated with higher sales rates, while some used markets for destocking during drought periods and restocking after droughts.

While also far (approximately $640 \mathrm{~km}$ ) from BMC headquarters, the Ghanzi area did not experience as much hardships in accessing markets due to BMC's Direct Cattle Purchase Scheme which buys cattle directly from farmers and therefore reduces transport costs. Another added advantage is the Trans Kalahari Highway. According to ADBG (2011), the profitability of transporting cattle from Ghanzi to Lobatse has increased significantly due to a reduction in cattle weight loss from $12 \%$ to $6 \%$ and bruising, as well as reduced travelling time. ADBG (2011) further estimated losses from the trekking of cattle from Ghanzi to Lobatse to have amounted to BWP 4.8 million to 7.2 million $^{\mathrm{b}}$ (US $\$ 0.7$ million to 1.0 million) per year before construction of the tarred road.

That notwithstanding, some farmers still decry the high costs of transporting animals to the BMC abattoir in Lobatse. And because, for various reasons, the BMC can close and shut down operations for certain periods during the year, farmers are stuck with livestock even if they want to sell. This scenario in turn also lowers prices of animals 
due to limited selling outlets and thus translates into less profit for farmers. Other players ('speculators') also often come into the picture and buy young cattle cheaply, fatten them at feedlots and later sell them to the BMC and make higher returns. This usually affects and disadvantages pastoral households with smaller herds who have less bargaining power.

Sometimes the BMC abattoir can only absorb a fraction of cattle at a time, operating way below its full capacity. This quota limits the number of animals farmers can offload, and thus, it becomes even more costly to transport very few animals to Lobatse instead of a truck full of cattle to capitalize on economies of scale and maximize returns. Further compounding this problem for transport owners is the limited amount/absence of goods to carry back to pastoral areas after offloading cattle at the abattoir instead of trucks returning empty. This situation in turn hurts the BMC, as it becomes less efficient and in the process incurs high overhead costs per unit of throughput due to low supply of slaughter animals.

Improved access to markets also has other added benefits for pastoral households apart from livestock sales, such as ease of importing commercial livestock feed during extended periods of drought, securing livestock drugs and vaccines as well as borehole equipment and spares.

\section{Complex system, no easy fix}

In light of the preceding constraints, finding clear-cut mitigation measures is a daunting task in a complex ecological and socio-economic system. Nonetheless, an attempt at some policy considerations is made.

\section{Communal pastoral system is here to stay}

The communal pastoral system in Botswana needs to be acknowledged as a selfsustaining livelihood strategy in supposedly marginal land, complete with its own ecological, biological and social dynamics. Once this is recognized, then policies which continuously strive to 'rescue' and 'modernize' pastoral communities will be reconsidered. For example, current policy will push for some form of exclusion (fencing) when confronted with the preceding challenges in the study areas such as stray animals, livestock predation, stock theft, involvement of livestock in road accidents, livestock diseases and uncontrolled breeding. This strategy, however, will play right into the hands of proponents of fencing of the commons. Instead, policy should 'think beyond the fence' and lobby for the resuscitation of traditional natural resource management institutions at the local level, with more jurisdictions over land use. Also, to avoid the continued underestimation of the importance of livestock in national statistics, the capture of field data should also be modified to include non-monetary uses of livestock at the local level, such as animals used in paying bride price (bogadi) or goats slaughtered for home consumption or social events.

\section{Improve land tenure security}

Further complicating the current policy drive is that Batswana rural communities (and still some urbanites) are entrenched in livestock farming, so there simply is not enough land to be demarcated into viable ranches for everyone, not now and certainly not in future. Communal pastoral land is further shrinking through demarcation for private livestock and wildlife ranching, crop farming, human settlements and other uses. As it 
is now, the push for fencing of the commons is so strong that even some communal pastoral households aspire to own or lease private ranches, if not for production then certainly for the prestige attached to it. This in itself is a reflection of the insecurity associated with communal land tenure.

\section{Increase involvement of stakeholders}

While commendable effort has been made to provide pastoral fora, mainly through groupings of livestock producers or Associations in Botswana, there is need to continuously involve the poorer pastoralists and avoid hijacking of such associations by richer and more powerful pastoralists. That way, a more representative voice of pastoral challenges and aspirations can be heard. Worryingly, the non-governmental organizations (NGOs) in Botswana rarely advocate for preservation of communal pastoral land use. Instead, topical issues for NGOs are wildlife-related and occasionally livestock health, with the latter often emphasizing the need for proper 'modern' management practices. This should be rectified. Financial challenges for pastoralists like expensive borehole drilling and livestock feeds can be alleviated through increased access to credit from financial institutions, which also need to come on board and tailor their products to suit the complexity of pastoral systems.

\section{Restructure and facilitate access to markets}

While not discouraging high-value beef export market to Europe, the Policy Framework for Pastoralism in Africa (AU 2010) stresses the need to pay more attention to markets within Africa and to foster regional trade, as well as tapping into the growing markets in the Middle East and Southeast Asia. These markets are relatively less stringent in terms of animal husbandry standards which make it less expensive and therefore easier for smallscale pastoralists to sell. And the timing is apt. For example, local beef consumption in Botswana has risen over the years and gradually reduced BMC's market share from $80 \%$ in 1981 to $44 \%$ in 2002 (CAR 2005). Considering that despite (or because of) government protection, $\mathrm{BMC}$ is running aground after years of posting record losses, a thorough overhaul and restructuring of the BMC is needed, or alternatively BMC's monopoly should be ended and the beef industry market liberalized - whichever is in the best interests of the livestock industry. Another market-related point is that pastoral households, especially those with fewer herds, tend to sell in order to have immediate cash in hand and do not have the luxury of applying for quotas to sell animals beforehand or waiting for days for the BMC to process their payments after selling (often cheques or electronic money transfers into the sellers' bank accounts).

The Policy Framework (AU 2010) further emphasizes the need to retain value locally through more processing of livestock products where economically viable - opportunities which pastoral communities can benefit from while the government can increase its revenue.

\section{Value indigenous knowledge}

Resilient pastoral communities possess a body of knowledge which has evolved over the years. Lately, research institutions in Botswana (e.g. The Centre for Scientific Research, Indigenous Knowledge and Innovation hosted by the University of Botswana) and the government (primarily through the Ministry of Infrastructure, Science and Technology) have demonstrated keen interest in unearthing and capturing indigenous technical knowledge of 
rural communities, as well as developing a policy on indigenous knowledge systems. This is a positive development, though still in its infancy. The accumulated and refined knowledge base includes, but is by no means restricted to, weather forecasts and precipitation indicators, livestock health problems, important poisonous or injurious plants, range degradation and drought mitigation strategies (e.g. Dube and Sekhwela 2008; Cassidy et al. 2011; Mogotsi et al. 2011b, Motlhanka and Nthoiwa 2013). Pastoral communities also traditionally had safety nets for the less privileged members of their society. If policy can tap into these indigenous knowledge systems, support and strengthen them, then more effective and efficient use of natural resources can be realized.

\section{Develop area-specific disaster management systems}

Pastoral areas are not immune to uncontrolled veld fires, droughts, floods and epidemic diseases. In the case of Kgalagadi and Ghanzi where recurrent droughts are common, interventions ought to be tailored to local conditions. The current 'blanket' aid programmes which might be appropriate in one Sub-district may not necessarily reduce household vulnerability to drought in another area and might instead reinforce the negative effects of drought (Mogotsi et al. 2012). For example, livestock feed subsidies may not be the most appropriate response in an area experiencing serious shortage of drinking water for livestock. Nor is subsidizing prices of concentrates desirable, when there is not enough roughage to sustain animals through the drought. Nor is encouraging destocking effective through increase of BMC prices, when already-weak animals have to be moved long distances and quarantined in some cases before reaching the market. Also, death of some animals during droughts should not always be viewed with alarm, as this is a natural regulatory mechanism of the semi-arid pastoral system. Interestingly, it may also be economically sensible for the farmer to let the animal die rather than to try to save it. But by making available highly subsidized commercial livestock feed during droughts, the government is inadvertently encouraging pastoralists to keep an artificial high number on a stressed ecosystem. Instead, if traditional communityspecific and modern disaster management approaches are merged, then better earlywarning, actual-event and post-disaster response measures can be formulated.

\section{Conclusions}

Extensive pastoral systems of the Kalahari remain central to rural livelihoods. The challenges presented in this study act concomitantly to exert pressure on, and erode resilience of, pastoral households and subsequently expose the system to risk. If these issues are honestly recognized and addressed through deliberately targeted policy interventions, then the long-term sustainability of extensive pastoralism can be assured, failing which, the non-pastoral sectors should be ready and willing to find an alternative, albeit more expensive, economic activity to support the 'once upon a time' pastoral population. Prospects for success of extensive pastoral systems in semi-arid regions such as Botswana lie in the overriding importance of collective management and flexibility, more so in a changing global climate.

\section{Endnotes}

${ }^{a}$ Following Elhadi et al. (2012), a household refers to all people who live under one roof and are subject to decisions made by the household head. The latter is the owner 
of the main source of income or means of production in a household and therefore provides the basic needs for the household members.

\section{${ }^{\mathrm{b}} \mathrm{US} \$ 1=6.97 \mathrm{BWP}$.}

\section{Competing interests}

The authors declare that they have no competing interests.

\section{Authors' contributions}

DM conceived the study idea, collected and interpreted data as well as drafting of the manuscript. KM improved the initial draft, interpreted data and drafted the manuscript. Both authors read and approved the final manuscript.

\section{Author details}

${ }^{1}$ Animal Production and Range Research Division, Department of Agricultural Research, Ministry of Agriculture, Private Bag 0033, Sebele, Botswana. ${ }^{2}$ Animal Production and Range Research Division, Department of Agricultural Research, Ministry of Agriculture, P. O. Box 10275, Francistown, Botswana.

\section{Received: 19 February 2013 Accepted: 18 June 2013}

Published: 5 July 2013

\section{References}

Abel, N. 1997. Mis-measurement of the productivity and sustainability of African communal rangelands: a case study and some principles from Botswana. Ecological Economics 23: 113-133.

ADBG. 2011. Botswana: Trans-Kgalagadi road project. Project performance evaluation report.Operations Evaluation Department, Project and Program Evaluation Division, African Development Bank Group. http://www.afdb.org/ fileadmin/uploads/afdb/Documents/Evaluation-Reports/Botswana-PPER_FINAL-May\%20Final.pdf. Accessed 31 Jan 2013.

APRU. 1980. Beef production and range management in Botswana. Gaborone: Animal Production and Range Research Unit, Ministry of Agriculture.

AU. 2010. Policy framework for pastoralism in Africa: Securing, protecting and improving the lives, livelihoods and rights of pastoralist communities. Addis Ababa: Department of Rural Economy and Agriculture, African Union.

Barrow, E, J Davies, S Berhe, V Matiru, N Mohamed, W Olenasha, and M Rugadya. 2007. Pastoralists as shrewd managers of risk and resilience in the Horn of Africa. Policy Brief No. 1 of 5. Nairobi: IUCN Eastern Africa Regional Office.

Behnke, R. 1985. Measuring the benefits of subsistence versus commercial livestock production in Africa. Agricultural Systems 16(2): 109-135.

Behnke, R. 2008. The economic contribution of pastoralism: Case studies from the Horn of Africa and southern Africa. Nomadic Peoples 12: 45-79.

Behnke, RH, I Scoones, and C Kerven. 1993. Range ecology at disequilibrium: New models of natural variability and pastoral adaptation in African Savannas. London: Overseas Development Institute.

Bhalotra, YPR. 1987. The drought of 1981-87 in Botswana. Gaborone: Department of Meteorological Services.

BIDPA. 2006. Prospects for export diversification in Botswana. Botswana Institute for Development Policy Analysis/World Bank report. http://www.bidpa.bw/img_upload/pubdoc_20.pdf. Accessed 10 Apr 2013.

Burgess, J. 2002. Botswana: Country pasture/forage resource profile. Food and Agriculture (FAO) report. http://www.fao. org/ag/AGP/AGPC/doc/Counprof/Botswana/botswana.htm. Accessed 19 Apr 2012.

CAR. 2005. Crop-livestock systems development in southern Africa: Priorities for future research. Botswana country report. Gaborone: Centre for Applied Research.

CAR. 2006. Environmental assessment of Botswana's livestock sector. Centre for Applied Research report. Ministry of Finance and Development Planning: Gaborone.

Carl Bro International. 1982. An evaluation of livestock management and production in Botswana with special reference to the communal areas, vol. 1-111. Gaborone: Evaluation Unit, Ministry of Agriculture and the Commission of the European Communities European Development Fund.

Cassidy, L, J Wilk, DL Kgathi, H Bendsen, BN Ngwenya, and K Mosepele. 2011. Indigenous knowledge, livelihoods and government policy in the Okavango Delta, Botswana. In Rural livelihoods and political economy, ed. DL Kgathi, BN Ngwenya, and J Wilk, 75-97. New York: Nova Science Publishers.

Chadwick, K, J Otte, and D Roland-Holst. 2008. Information failures in livestock markets: Evidence from Lao PDR. Pro-Poor Livestock Policy Initiative.A Living from Livestock.Research report. Rome: FAO.

Coppock, DL, and S Sovani. 1999. Is supplementation justified to compensate pastoral calves for milk restriction? Journal of Range Management 52: 208-217.

Darkoh, MBK, and JE Mbaiwa. 2003. Globalization and the livestock industry in Botswana. Singapore Journal of Tropical Geography 23: 149-166.

Davies, J, and R Hatfield. 2007. The economics of mobile pastoralism: A global summary. Nomadic Peoples 11: 91-116.

Delgado, C, M Rosegrant, H Steinfeld, S Ehui, and C Courbois. 1999. Livestock to 2020: The next food revolution. 2020 vision discussion paper. Washington, DC: International Food Policy Research Institute.

deRidder, N, and KT Wagenaar. 1986. Energy and protein balances in traditional livestock systems and ranching in eastern Botswana. Agricultural Systems 20: 1-16.

deVries, JJ, ET Selaolo, and HE Beekman. 2000. Groundwater recharge in the Kalahari, with reference to paleo-hydrologic conditions. Journal of Hydrology 238: 110-123.

DFID. 2011. Pastoralism: Progressing policies that favour pastoralists. Facilitating access to world markets.Department for International Development. http://www.dfid.gov.uk/r4d/Output/187272/Default.aspx. Accessed 18 Dec 2012.

Dube, OP, and MBM Sekhwela. 2008. Indigenous knowledge, institutions and practices for coping with variable climate in the Limpopo Basin of Botswana. In Climate change and adaptation, ed. N Leary, J Adejuwon, V Barros, I Burton, J Kulkarni, and R Lasco, 71-89. London: Earthscan. 
duPlessis, AJE, and KM Rowntree. 2003. Water resources in Botswana with particular reference to the Savanna regions. South African Geographical Journal 85: 42-49.

Elhadi, YAM, DM Nyariki, VO Wasonga, and WN Ekaya. 2012. Transient poverty among pastoral households in the semi-arid lowland of Baringo district, Kenya. Ozean Journal of Social Sciences 5: 9-19.

ESAP. 2003. Challenges and opportunities of livestock marketing in Ethiopia. In Proceedings of the 10th annual conference of the Ethiopian Society of Animal Production (ESAP) held August 22-24 in Addis Ababa, Ethiopia, ed. Y Jobre and G Gebru.

Fako, TT, and L Molamu. 1995. The seven-year drought, household food security and vulnerable groups in Botswana. Pula: Botswana Journal of African Studies 9: 48-70.

FAO. 2001. Pastoralism in the new millennium. FAO Animal Production and Health Paper 150. http://www.fao.org/ docrep/005/y2647e/y2647e00.htm\#toc. Accessed 9 Jan 2013.

FAO. 2009. Review of evidence on drylands pastoral systems and climate change: Implications and opportunities for mitigation and adaptation. Land and Water Discussion Paper 8. Rome: FAO.

Flintan, F, and A Cullis. 2010. Introductory guidelines to participatory rangeland management in pastoral areas. Addis Ababa: Save the Children/US.

Fraser, EDG, AJ Dougill, WE Mabee, M Reed, and P McAlpine. 2006. Bottom up and top down: analysis of participatory processes for sustainability indicator identification as a pathway to community empowerment and sustainable environmental management. Journal of Environmental Management 78: 114-127.

Frimpong, K. 1995. A review of the tribal grazing land policy in Botswana. Pula: Botswana Journal of African Studies 9: 1-16. GoB. 1975. National policy on tribal grazing land. Paper No. 2 of 1975. Gaborone: Government of Botswana.

GoB. 1991. National policy on agricultural development. Gaborone: Ministry of Agriculture, Government of Botswana.

GoB. 1999. Community-based natural resource management practitioners guide. Gaborone: Department of Wildlife and National Parks, Government of Botswana.

GoB. 2002. Revised national policy for rural development. Ministry of Finance and Development Planning, White Paper No. 3. Gaborone: Government of Botswana.

GoB. 2005. Wildlife Conservation and National Parks (Lions) (Killing Restriction) Order. Gaborone: Department of Wildlife and National Parks, Government of Botswana.

GoB. 2009a. Final report on establishment of the Botswana vulnerability assessment and analysis system for national food security. Gaborone: Government of Botswana.

GoB. 2009b. New compensation policy. Gaborone: Department of Wildlife and National Parks, Government of Botswana.

GoB. 2011. Crime prevention guidelines for livestock. Gaborone: Government of Botswana. http://www.gov.bw/en/ Ministries-Authorities/Ministries/State-President/Botswana-Police-Service-/About-the-BPS/Stock-Theft-Branch/ Accessed 12 Jan 2013

GoB. 2013. Annual agricultural surveys preliminary results for 2011. Gaborone: Government of Botswana. http://www cso.gov.bw. Accessed 7 June 2013.

Greenhow, T. 1978. The Tribal Grazing Land Policy and integrated land-use planning: A district view. Botswana Notes and Records 10: 159-168.

Hardin, G. 1968. The tragedy of the commons. Science 162: 1243-1248.

Hartter, J, A Goldman, and J Southworth. 2011. Responses by households to resource scarcity and human-wild life conflict: Issues of fortress conservation and the surrounding agricultural landscape. Journal for Nature Conservation 19: 79-86.

Hendrickson, D, J Armon, and R Mearns. 1996. Livestock raiding among the pastoral Turkana of Kenya: Redistribution, predation and the links to famine. Institute of Development Studies Bulletin 27: 17-30.

Hitchcock, RK. 1978. Kalahari cattle posts: A regional study of hunter-gatherers, pastoralists and agriculturalists in the Western Sandveld Region, vol. I. Preliminary draft. Gaborone: Ministry of Local Government and Lands.

Holm, JD, and RG Morgan. 1985. Coping with drought in Botswana: An African success. Journal of Modern African Studies 23: 463-482.

IFAS. 1998. The disaster handbook. National Edition Publication DH 1605. Gainesville: Institute of Food and Agricultural Sciences, University of Florida.

Jefferis, K. 2005. How trade liberalization can contribute to revitalise Botswana's beef and cattle sector. Proceedings of the Botswana Agricultural Research Information Network (BARIN) conference, 24-26 May 2005, Sebele, Botswana.

Kaimba, GK, BK Njehia, and AY Guliye. 2011. Effects of cattle rustling and household characteristics on migration decisions and herd size amongst pastoralists in Baringo District, Kenya. Pastoralism: Research, Policy and Practice 1: 18.

Keijsper, V. 1993. Livestock development in Botswana: Consequences for the rural poor. Africa Spectrum 28: 323-339.

Kgathi, DL. 1999. Water demand, population and sustainability in Botswana: Implications for development policy. A paper prepared for the Population, Development and Environment Project. Luxembourg: International Institute for Applied Systems Analysis.

Kgathi, DL, G Mmopelwa, B Mashabe, and K Mosepele. 2012. Livestock predation, household adaptation and compensation policy: A case study of Shorobe village in northern Botswana. Agrekon: Agricultural Economics Research, Policy and Practice in Southern Africa 51: 22-37.

Kgosikoma, OE. 2006. Effects of climate variability on livestock population dynamics and community drought management in Kgalagadi, Botswana. MSc thesis. Norwegian University of Life Sciences, Norway.

McPeak, J. 2001. Pastoralists' use of markets. Pastoral Risk Management Project Research Brief 01-04-PARIMA. Davis: Global Livestock Collaborative Research Support Program.

Mkutu, KA. 2010. Complexities of livestock raiding in Karamoja. Nomadic Peoples 14: 87-105.

Mogotsi, K, MM Nyangito, and DM Nyariki. 2011a. The perfect drought? Constraints limiting Kalahari agro-pastoral communities from coping and adapting. African Journal of Environmental Science and Technology 5: 168-177.

Mogotsi, K, AB Moroka, O Sitang, and R Chibua. 2011 b. Seasonal precipitation forecasts: Agro-ecological knowledge among rural Kalahari communities. African Journal of Agricultural Research 6: 916-922.

Mogotsi, K, MM Nyangito, and DM Nyariki. 2012. Vulnerability of rural agro-pastoral households to drought in semi-arid Botswana. Livestock Research for Rural Development24(10),Article \#183. http://www.lrrd.org//rrd24/10/mogo24183.htm. Accessed 15 December 2012 
Mogotsi, K, MM Nyangito, and DM Nyariki. 2013. The role of drought among agro-pastoral communities in a semi-arid environment: The case of Botswana. Journal of Arid Environments 91: 38-44.

Mothanka, DMT, and GP Nthoiwa. 2013. Ethnobotanical survey of medicinal plants of Tswapong North, in Eastern Botswana: A case of plants from Mosweu and Seolwane villages. European Journal of Medicinal Plants 3: 10-14.

Mrema, M, and S Rannobe. 1996. Goat production in Botswana: Factors affecting production and marketing among small-scale farmers. In Small ruminant research and development in Africa. Proceedings of the third biennial conference of the African Small Ruminant Research Network, Kampala, Uganda, ed. SHB Lebbie and E Kagwini, 105-109. Nairobi: International Livestock Research Institute (ILRI). http://www.fao.org/wairdocs/liri/x5473b/x5473b0v.htm. Accessed 17 November 2012

Niamir-Fuller, M, C Kerven, R Reid, and E Milner-Gulland. 2012. Co-existence of wildlife and pastoralism on extensive rangelands: Competition or compatibility? Pastoralism: Research. Policy and Practice 2: 8.

Nori, M, J Switzer, and A Crawford. 2005. Herding on the brink: Towards a global survey of pastoral communities and conflict.An occasional paper from the IUCN Commission on Environmental, Economic and Social Policy; Gland (Ch). http://www.iisd.org/pdf/2005/security_herding_on_brink.pdf. Accessed 4 October 2012

Omosa, EK. 2005. The impact of water conflicts on pastoral livelihoods: The case of Wajir District in Kenya. Winnipeg: International Institute for Sustainable Development.

Pica-Ciamarra, U, J Otte, and C Martini. 2010. Livestock sector policies and programmes in developing countries - a menu for practitioners. Food and Agriculture Organization (FAO): Rome.

Sandford, S. 1979. Toward a definition of drought. In proceedings of the symposium on drought in Botswana. Gaborone: Botswana Society.

SAS. 2005. SAS/STAT user's guide. Cary: SAS (Statistical Analysis Systems) Institute Inc.

Schilling, J, FEO Opiyo, and J Scheffran. 2012. Raiding pastoral livelihoods: Motives and effects of violent conflict in north-western Kenya. Pastoralism: Research, Policy and Practice 2: 25.

Scoones, I. 1995. New directions in pastoral development in Africa. In Living with uncertainty: New directions in pastoral development in Africa, ed. I Scoones, 1-36. London: Intermediate Technology Publications Ltd.

Thomas, DSG, and D Sporton. 1997. Understanding the dynamics of social and environmental variability: The impacts of structural land use change on the environment and peoples of the Kalahari, Botswana. Applied Geography 17: $11-27$.

Thomas, DSG, D Sporton, and J Perkins. 2000. The environmental impact of livestock ranches in the Kalahari, Botswana: Natural resource use, ecological change and human response in a dynamic dryland system. Land Degradation and Development 11: 327-341.

Thurow, TL, and CA Taylor Jr. 1999. Viewpoint: The role of drought in range management. Journal of Range Management 52: 413-419.

Tsimako, B. 1991. The Tribal Grazing Land Policy ranches: Performance to date. Gaborone: Ministry of Agriculture.

Twyman, C. 2001. Natural resource use and livelihoods in Botswana's Wildlife Management Areas. Applied Geography 21: 45-68.

White, R. 1993. Livestock development and pastoral production on communal rangeland in Botswana. Gaborone: The Botswana Society.

Wilhite, DA, and MH Glantz. 1985. Understanding the drought phenomenon: The role of definitions. Water International 10: $111-120$.

doi:10.1186/2041-7136-3-18

Cite this article as: Mosalagae and Mogotsi: Caught in a sandstorm: an assessment of pressures on communal

pastoral livelihoods in the Kalahari Desert of Botswana. Pastoralism: Research, Policy and Practice 2013 3:18.

\section{Submit your manuscript to a SpringerOpen ${ }^{\circ}$ journal and benefit from:}

- Convenient online submission

- Rigorous peer review

- Immediate publication on acceptance

- Open access: articles freely available online

- High visibility within the field

- Retaining the copyright to your article

Submit your next manuscript at $\boldsymbol{~ s p r i n g e r o p e n . c o m ~}$ 